\title{
$\beta$-Glucosidase Activity in Mycoplasma
}

\author{
By C. V. HENRIKSON AND P. F. SMITH \\ Department of Microbiology, School of Medicine, University of South Dakota, \\ Vermillion, South Dakota, U.S.A.
}

(Received 30 April 1964)

\section{SUMMARY}

Strains of three groups of Mycoplasma with different nutritional requirements were analysed for $\beta$-glucosidase activity. The enzyme was found in the cell membrane of Mycoplasma laidlawii strain B and $M$. gallisepticum strain $\mathrm{J}$, which metabolize carbohydrates; negligible $\beta$ glucosidase activity was found in $M$. hominis strain 07 which does not metabolize carbohydrates. $\beta$-Glucosidase in all strains was inactivated by heating at $56^{\circ}$ for $30 \mathrm{~min}$. or at $100^{\circ}$ for $10 \mathrm{~min}$. With $M$. laidlarvii strain B as the test organism, $\beta$-glucosidase was found to possess the following characteristics: $\mathrm{pH}$ optimum, $6 \cdot 8$; optimum temperature, $30^{\circ}$; no dialysable cofactors required; phosphate ions had no effect on activity; enzyme was specific for substrates (glucosides) with $\beta$ configuration; aglycon of the glucoside must be an aryl group; enzyme exhibited absolute specificity for carbon atoms number 4 and 5 of the glycon. The presence of $\beta$-glucosidase in $M$. laidlawii strain $\mathbf{B}$ and $M$. gallisepticum strain $\mathbf{J}$ is assumed to be involved in the synthesis and hydrolysis of carotenyl glucoside and sterol glucoside by these organisms.

\section{INTRODUCTION}

Mycoplasma organisms can be divided into three groups on the basis of nutritional requirements: Mycoplasma laidlawii strain в is representative of a group which does not require a sterol as a nutrient and which metabolizes carbohydrates; $M$. gallisepticum strain $\mathrm{J}$ belongs to a group which requires a sterol and metabolizes carbohydrates (Rothblat \& Smith, 1961); $M$. hominis strain 07 belongs to a group which requires a sterol but does not metabolize carbohydrates.

Strains of the third group ( $M$. hominis strain 07 ) contain free and esterified sterol (Smith, 1959). The group represented by $M$. gallisepticum strain J contains free and esterified sterol and steryl-glucoside. When cholesterol is the sterol source, the glucoside is a cholesteryl- $\beta$-D-glucoside. The amount of steryl-glucoside has been shown to be related to the amount of glucose added to the culture medium (Rothblat $\&$ Smith, 1961). The group represented by $M$. laidlawii strain B contains nonsaponifiable lipids comprised of carotenoids which are synthesized de novo; however, these organisms are also capable of incorporating sterol which spares carotenoid synthesis (Smith, 1963a). This sparing action suggested a similarity in function of sterol and carotenoids.

One function of the non-saponifiable lipids in Mycoplasma is believed to be structural since sterol is incorporated into the cell membrane and is not metabolized. Another possible function is that the sterol or carotenol may act as carriers of metabolizable substrates into the cell and of metabolic end-products out of the cell 
(Smith, 1963b). No direct demonstration of glucosidases in Mycoplasma has hitherto been made, although their presence was suspected since the organisms contain glucosides. The present work demonstrates $\beta$-glucosidase activity in the cell membrane of glucose-fermenting strains but a negligible activity in one strain which does not ferment glucose.

\section{METHODS}

Organisms. Six representative strains of Mycoplasma were examined. The saprophytic strains $M$. laidlawii strains A and B, $M$. inocuum, and the unclassified strain KHS of caprine origin which do not need a sterol as nutrient and utilize carbohydrates; $\boldsymbol{M}$. gallisepticum strain $\mathbf{J}$ which requires sterol and utilizes carbohydrates; $M$. hominis strain 07 which requires sterol and does not utilize carbohydrates. All of the above strains have been maintained in this laboratory.

Media. Saprophytic strains were grown in a tryptose broth of the following composition: $2 \%$ tryptose (Difco); $0.5 \%$ sodium chloride; $0.5 \%$ sodium acetate;

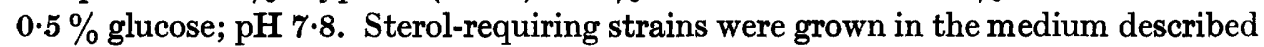
by Morton, Smith \& Leberman (1951) supplemented with $1 \%$ Bacto PPLO serum fraction (Difco). The medium for $M$. gallisepticum strain J was supplemented with $0.5 \%$ glucose.

Cultivation. The organisms were grown and harvested as has been reported (Smith, 1955). The amounts of organisms were measured on the basis of total cellular N (Lecce \& Morton, 1954). Thallium acetate $1 / 2500(w / v)$ was used as a selective inhibitor of bacterial growth. The presence of this inhibitor had no effect on glucosidase activity. The organisms were resuspended in $\mathrm{M} / 15 \mathrm{pH} 7 \cdot 5$ phosphate buffer for most experiments although tris-hydroxymethylamino-methane-maleate buffer (tris-maleate; Gomori, 1955) was used for various determinations.

Enzymic activity. In most experiments, the enzymic activity was determined by spectrophotometric measurement at $400 \mathrm{~m} \mu$ of the amount of $p$-nitrophenol released from $p$-nitrophenyl- $\beta$-D-glucoside (Duerksen \& Halvorson, 1958). The activity of the enzyme toward 0 -nitrophenyl- $\beta$-D-galactoside as substrate was determined in a similar fashion. The procedure was modified by diluting the test samples in $0.1 \mathrm{~N}$-sodium hydroxide instead of phosphate buffer ( $\mathrm{pH} 11$ ) to assure a maximum colour development. For substrates with non-coloured aglycons, the activity was determined by measuring the amount of reducing sugar released (Park \& Johnson, 1949). Since intact organisms would metabolize the liberated sugar, the organisms were disrupted in a $10 \mathrm{Kc}$ Raytheon oscillator $(10 \mathrm{~min}$.) and dialysed for $48 \mathrm{hr}$ in $0.005 \mathrm{M}$ tris-maleate buffer ( $\mathrm{pH} \mathrm{7 \cdot 0)}$ ) to eliminate cofactors. Essentially no loss of glucosidase activity occurred as a result of the sonic treatment (see Results).

Chemicals. The substrates used were: $\boldsymbol{p}$-nitrophenyl- $\beta$-D-glucoside, $\boldsymbol{o}$-nitrophenyl$\beta$-D-galactoside, maltose, cellobiose, gentiobiose, $\alpha$-methyl-D-glucoside, $\beta$-methylD-glucoside, $\beta$-methyl-D-arabinopyranoside, $\beta$-methyl-L-arabinopyranoside, $\beta$ methyl-D-xylopyranoside, $\alpha$-methyl-D-xylopyranoside, 6-bromo-2-naphthyl- $\alpha$-Dglucoside, 6-bromo-2-naphthyl- $\beta$-D-glucoside and $\alpha$-methyl-D-mannopyranoside (California Corp. for Biochemical Research), amygdalin (Difco), salicin (Pfanstiehl Chemical Co.).

Enzyme localization. Distribution of enzyme activity was determined by use of 
sonically treated suspensions of Mycoplasma laidlawii strain в and $\boldsymbol{M}$. gallisepticum strain $\mathrm{J}$ and frozen-thawed suspensions (10 cycles) of $M$. laidlawii strain B. The broken suspensions were centrifuged in a Spinco Model $\mathrm{L}$ centrifuge $(94,500 \mathrm{~g})$ for $\mathbf{3 0} \mathrm{min}$. and the deposit resuspended in an equal volume of buffer. A fraction of intact organisms, sonically treated organisms, the centrifuged supernatant fraction, and the centrifuged deposit were each used as enzyme source.

Glucoside synthesis and transglycosidation. Analysis of reaction systems designed to demonstrate synthesis of glucosides and transglycosidation was done by chemical measurement of disappearance of substrate and by detection of glycosides on thinlayer chromatographs. The procedure for thin-layer chromatography was like that used by Gee (1963), with the difference that the developing solvent was chloroform + methanol + acetic acid + water $(65+25+8+4$, by vol. $)$.

\section{RESULTS}

Glucosidase activity was found in Mycoplasma laidlawii strain B (Fig. 1) and $M$. gallisepticum strain J, but no activity was found in $M$. hominis strain 07 (Fig. 2). That this activity was enzymic was supported by its lability to heat and its dependence upon the concentration of organisms. $M$. laidlawii strain B, heated at $100^{\circ}$ for $10 \mathrm{~min}$. or $56^{\circ}$ for $30 \mathrm{~min}$., showed complete loss of enzymic activity (Fig. 1 ). Increase in glucosidase activity towards $p$-nitrophenyl- $\beta$-D-glucoside was shown upon increase of organism concentration (Table 1). All readings were taken at time intervals indicative of enzyme saturation with substrate.

Table 1. Effect of cell concentration on $\beta$-glucosidase activity in Mycoplasma laidlawii strain $B$ and $M$. gallisepticum strain $J$

Reaction mixture; $p$-nitrophenyl- $\beta$-D-glucoside, $18 \mu$ mole; glutathione, $0.25 \mathrm{mg}$; $0.067 \mathrm{M}$-phosphate buffer ( $\mathrm{pH} 7 \cdot 5$ ); final volume, $3 \mathrm{ml}$. Reactions carried out $\mathrm{B} \mathrm{hr}$ at $30^{\circ}$ for $M$. laidlawii strain B and $37^{\circ}$ for $M$. gallisepticum strain $\mathrm{J}$.

$\begin{array}{ccc}\begin{array}{c}\text { Cell nitrogen } \\ \text { (mg.) }\end{array} & \begin{array}{c}\text { M. laidlawii } \\ \text { strain B } \\ p \text {-nitrophenol formed }(\mu \text { mole) }\end{array} & \begin{array}{c}M \text {. gallisepticum } \\ \text { strain J }\end{array} \\ 1 & \overbrace{2 \cdot 58} & 1 \cdot 17 \\ 2 & 3 \cdot 47 & 2 \cdot 10 \\ 3 & 4 \cdot 33 & 3 \cdot 00\end{array}$

The major activity was found in the residues (cell membranes) in contrast to the supernatant fluid fractions (cytoplasm) (Table 2), whether derived by sonic treatment or by freeze-thaw. These results were indicative of a membrane location for the glucosidase.

The optimal temperature for activity was the same as that for growth, i.e. $30^{\circ}$ for the saprophytic strains and $37^{\circ}$ for the sterol-requiring strains. The $\mathrm{pH}$ optimum was 6.8 although this optimum was not sharply defined (Table 3). In most experiments with whole organisms, there was a $2 \mathrm{hr}$ lag before activity became optimum (Fig. 1, 3). When the organisms were incubated at $30^{\circ}$ or $37^{\circ}$ for $24 \mathrm{hr}$, the lag period was eliminated (Fig. 3). Storage of Mycoplasma laidlawii strain в at $4^{\circ}$ for $72 \mathrm{hr}$ or at room temperature for $24 \mathrm{hr}$ had little effect on glucosidase activity. Glucosidase activity of intact $M$. laidlarwii strain B against $p$-nitrophenyl- $\beta$-D-glucoside in 
$0 \cdot 048 \mathrm{M}$ - tris-maleate buffer $(\mathrm{pH} 7 \cdot 0)$ was neither augmented nor decreased by the addition of di-basic sodium phosphate in equimolar proportion to the substrate. Material from organisms after sonic treatment and also after subsequent dialysis showed about the same activity.

Table 2. Distribution of $\beta$-glucosidase activity in Mycoplasma laidlawii, strain B and $M$. gallisepticum

Reaction conditions same as Table 1 with the exception that $6 \mu$ mole of $p$-nitrophenyl$\beta$-D-glucoside was used.

\section{Fraction of organism}

Control (whole organisms)

Residue fraction

Supernatant fraction

Activity in residue fraction (\%)

\begin{tabular}{|c|c|c|}
\hline \multicolumn{2}{|c|}{ Sonic treatment } & \multirow{2}{*}{$\begin{array}{c}\text { Freeze-thaw } \\
M . \text { laidlawii } \\
\text { strain B }\end{array}$} \\
\hline $\begin{array}{l}M . \text { laidlawii } \\
\text { strain B }\end{array}$ & $\begin{array}{c}M . \text { gallisepticum } \\
\text { strain J }\end{array}$ & \\
\hline \multicolumn{3}{|c|}{$p$-nitrophenol formed ( $\mu$ mole) } \\
\hline 4.52 & $4 \cdot 44$ & $4 \cdot 86$ \\
\hline $\mathbf{3} \cdot \mathbf{5 9}$ & 3.72 & $4 \cdot 43$ \\
\hline 0.61 & 0.42 & 0.34 \\
\hline $81 \cdot 9$ & $84 \cdot 0$ & $91 \cdot 15$ \\
\hline
\end{tabular}

Table 3. Effect of $p H$ value on $\beta$-glucosidase activity in Mycoplasma laidlawii strain $B$

Reaction mixture same as Table 1 except 0.048 M-tris-maleate buffer and $6 \mu$ mole $p$-nitrophenol- $\beta$-D-glucoside were used.

\begin{tabular}{|c|c|c|c|}
\hline $\mathrm{pH}$ value & $\begin{array}{l}p \text {-Nitrophenol formed } \\
\qquad(\mu \text { mole })\end{array}$ & pH value & $\begin{array}{l}p \text {-Nitrophenol formed } \\
(\mu \text { mole })\end{array}$ \\
\hline $\mathbf{5} \cdot \mathbf{3 3}$ & 0.54 & $7 \cdot 02$ & $2 \cdot 97$ \\
\hline $5 \cdot 80$ & 1.59 & $7 \cdot 19$ & $2 \cdot 64$ \\
\hline $5 \cdot 90$ & $2 \cdot 13$ & 7.50 & $2 \cdot 64$ \\
\hline 6.50 & $2 \cdot 46$ & 8.00 & $2 \cdot 25$ \\
\hline 6.60 & $2 \cdot 64$ & $8 \cdot 10$ & $2 \cdot 13$ \\
\hline $6 \cdot 80$ & $8 \cdot 21$ & 8.45 & 2.04 \\
\hline
\end{tabular}

The specificity of the glucosidases found in various strains of Mycoplasma is shown in Table 4. All strains hydrolysed $p$-nitrophenyl- $\beta$-D-glucoside. Mycoplasma laidlawii strains $\mathbf{A}$ and $\mathbf{B}$, showed very small activity with $o$-nitrophenyl- $\beta$-Dgalactoside, and no activity was shown by the caprine strain KHS and $M$. inocuum. Amygdalin was partially hydrolysed by the caprine strain KHs and by $M$. laidlawii strain B. All organisms capable of glucose degradation partially hydrolysed salicin. The caprine strain KHS and $M$. laidlawii strain B, hydrolysed 6-bromo-2-naphthyl$\beta-\mathrm{D}$-glucoside, for which no activity was shown by $\boldsymbol{M}$. laidlareii strain $\mathrm{A}$ and $\boldsymbol{M}$. inocuum. No activity was shown by any strain with 6-bromo-2-naphthyl- $\alpha$-Dglucoside, $\alpha$-maltose, cellobiose, gentiobiose, $\alpha$-methyl-D-glucoside, $\beta$-methyl-Dglucoside, $\beta$-methyl-D-arabinopyranoside, $\beta$-methyl-L-arabinopyranoside, $\beta$-methylD-xylopyranoside, $\alpha$-methyl-D-xylopyranoside, $\alpha$-methyl-D-mannopyranoside.

Inhibition of $p$-nitrophenyl- $\beta$-D-glucoside hydrolysis by Mycoplasma laidlazii strain B occurred when amygdalin was added (Table 5).

Attempts were made to synthesize glycosides with $M$ ycoplasma laidlawii strain B. No synthesis of $p$-nitrophenyl- $\beta$-D-glucoside, i.e. on decrease in optical extinction 
at $400 \mathrm{~m} \mu$, was found in the presence of glucose and $p$-nitrophenol. Likewise, no disappearance of glucose occurred when this was incubated with dialysed sonically treated organisms + cholesterol. Uridine diphosphate glucose (UDPG) did not act as a glucose donor with $p$-nitrophenol. This inactivity of UDPG was not due to its degradation since no free glucose appeared upon incubation of this compound with the enzyme preparation in the presence or absence of $0.01 \mathrm{M}$-sodium fluoride.

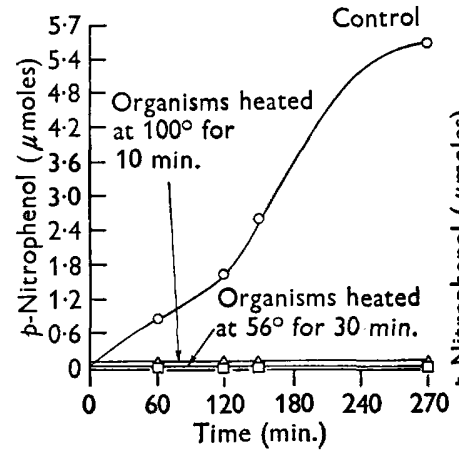

Fig. 1

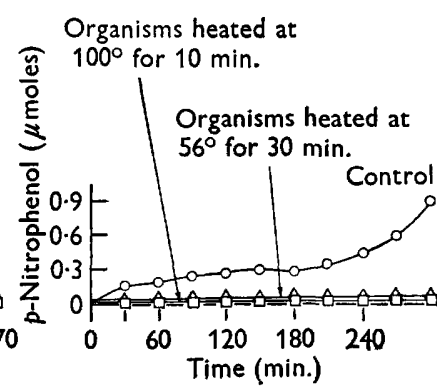

Fig. 2

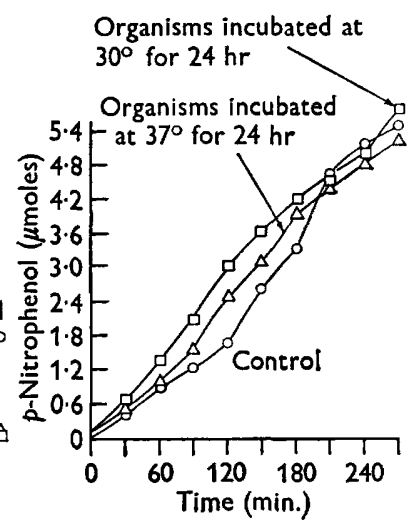

Fig. 3

Fig. 1. $\beta$-Glucosidase activity in Mycoplasma laidlawii strain B. Reaction mixture: $p$-nitrophenyl- $\beta$-D-glucoside, $6 \mu$ mole; glutathione, $0.25 \mathrm{mg}$.; $\mathrm{M} / 15$ phosphate buffer (pH $7 \cdot 5$ ); organism equivalent to $2 \mathrm{mg}$. cellular- $\mathrm{N}$; final volume, $3 \mathrm{ml}$. Reaction time, 3.0 hr at $30^{\circ}$.

Fig. 2. $\beta$-Glucosidase activity in Mycoplasma hominis strain 07. Reaction mixture same as in Fig. 1.

Fig. 3. Effect of preincubation on $\beta$-glucosidase activity in Mycoplasma laidlawii strain B. Reaction mixture same as in Fig. 1 .

\section{Table 4. Specificity for aryl glucosides by $\beta$-glucosidases in saprophytic Mycoplasma strains}

Reaction mixture same as Table 1 except for substrate variation. Each substrate added at $6 \mu$ mole.

\section{Substrate}

$p$-Nitrophenyl- $\beta$-D-glucoside* $o$-Nitrophenyl- $\beta$-D-galactoside* Amygdalin $\uparrow$

Salicin $\dagger$

6-Bromo-2-naphthyl- $\beta$-D-glucoside $\dagger$

$$
\begin{gathered}
\text { Caprine strain } \\
\text { KHS } \\
(\mu \text { mole })
\end{gathered}
$$$$
\text { 4.10 }
$$$$
0
$$$$
0 \cdot 61
$$$$
0 \cdot 66
$$

$6 \cdot 00$

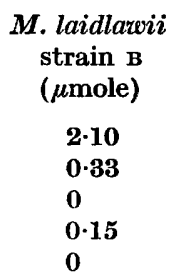

M. inocuum
( $\mu$ mole)

\section{M. laidlawii}

strain A

3.87

$0 \quad 0.39$

$0 \quad 0.96$

$0.17 \quad 0.15$

* Nitrophenol liberation measured spectrophotometrically at $400 \mathrm{~m} \mu$.

$\uparrow$ Glucose liberation measured by the method of Park \& Johnson (1949).

Transglycosidation experiments were made with $p$-nitrophenyl- $\beta$-D-glucoside as donor and methanol, propanol, or butanol as acceptors. Samples were analysed, with known glycosides, by thin-layer chromatography. No glycosides other than $p$-nitrophenyl- $\beta$-D-glucoside were detected. 
Table 5. Inhibition by amygdalin of p-nitrophenyl- $\beta$-D-glucoside hydrolysis in Mycoplasma laidlazii Strain $B$

Reaction mixture same as Table 1 with the following exceptions: $6 \mu$ mole of $p$ nitrophenyl- $\beta$-D-glucoside; amounts of amygdalin as shown.

$\begin{array}{ccc}\begin{array}{c}\text { Amygdalin } \\ (\mu \text { mole })\end{array} & \begin{array}{c}\text { Amygdalin/ } \\ p \text {-nitrophenyl- } \beta \text {-D-glucoside } \\ \text { ratio }\end{array} & \begin{array}{c}\text { Degree of } \\ \text { inhibition } \\ (\%)\end{array} \\ 0 & - & 0 \\ 1 \cdot 2 & 1 / 5 & 80 \cdot 0 \\ 6 \cdot 0 & 1 / 1 & 84 \cdot 1 \\ 12 & 2 / 1 & 96 \cdot 4 \\ 18 & 3 / 1 & 94 \cdot 6\end{array}$

\section{DISCUSSION}

The existence of significant glucosidase activity only in the strains of Mycoplasma which metabolized glucose and its location in the membrane fraction adds supporting evidence to the hypothesis of the role of sterols and carotenols in the membrane transport of glucose (Smith, 1963 b). Elimination of the lag in hydrolysis of $p$-nitrophenyl- $\beta$-D-glucoside by incubation of intact organisms for $24 \mathrm{hr}$ at $30^{\circ}$ or $37^{\circ}$ may be explained by hydrolysis of endogenous carotenyl or cholesteryl glucoside in the cell membrane (Smith, 1963b). It would be expected that the enzyme would preferentially attack the endogenous glucoside not only because it is the natural substrate but also because this substrate is located in the particulate cell-fraction which contains the enzyme. It is unlikely that the lag implicates an induction of the glucosidase since the organisms were grown"in the presence of glucose. Bacterial contamination cannot explain the lag, for no increase in bacterial counts were observed, with or without added thallium acetate, during the course of the reaction. Because of the lag two different reaction rates are evident. Therefore, all data presented in this paper were based on the reaction rate which occurred after the initial lag period. The change in rate of reaction after extended incubation, i.e. after $3 \mathrm{hr}$, was due no doubt to lack of sufficient substrate to saturate the enzyme or to end productinhibition.

The $\mathrm{pH}$ optimum of $\beta$-glucosidases is dependent on their source and to a minor degree on the substrate and the buffer (Veibel, 1950). The pH optimum of the $\beta$ glucosidases from Mycoplasma is relatively high $(\mathrm{pH} \mathrm{6.8)}$ as compared with $\beta$ glucosidases from other sources except that from Saccharomyces cerevisiae which has an optimum of $\mathrm{pH} 6 \cdot 4-6 \cdot 8$ (Duerksen \& Halvorson, 1958). The $\mathrm{pH}$ optima of $\beta$-glucosidases from other sources vary from $\mathrm{pH} 4$ to 5.8 (Veibel, 1950; Jermyn, 1955; Hash \& King, 1958; Conchie, 1954).

No added cofactors were required for activity, but this may be a reflexion of the particulate nature of the enzyme. Veibel (1950) demonstrated that the activity of $\beta$-glucosidase from almond emulsin doubled when the cations, sodium, potassium, rubidium, calcium, strontium, and barium, and the anions, nitrate, iodide, perchlorate, and chlorate, were added at $0.08 \mathrm{M}$ concentration. However, Duerksen $\&$ Halvorson (1958) demonstrated no difference in activity of $\beta$-glucosidase from Saccharomyces cerevisiae when the cations, sodium, potassium, ammonium, lithium, calcium, magnesium, and manganese, were added at $0 \cdot 1 \mathrm{~m}$ concentration. 
The glucosidase in Mycoplasma exhibits relative specificity in contrast to absolute specificity since more than one substrate can be attacked, i.e. $p$-nitrophenyl- $\beta$-Dglucoside, salicin, amygdalin, and 6-bromo-2-naphthyl- $\beta$-D-glucoside. The enzyme exhibits high bond specificity since only $\beta$-glucosides are attacked. High bond specificity also involves the nature of the bonded group such as sugar, alkyl, or aryl aglycons. The only substrates attacked by the enzyme were those with aryl aglycons. Substrates with $\alpha$ configuration, i.e. $\alpha$-maltose, $\alpha$-methyl-D-glucoside, 6-bromo-2-naphthyl- $\alpha$-D-glucoside and $\alpha$-methyl-D-mannopyranoside were not attacked by the enzyme which indicated that no $\alpha$-glucosidase was present. Cellobiose, which is of $\beta$ configuration, was not hydrolysed by any of the strains. Such results have been obtained with other organisms. Hash \& King (1958) demonstrated $\beta$-glucosidase in Myrothecium verrucaria which hydrolysed aryl $\beta$-glucosides but not cellobiose. Jermyn (1955) also demonstrated a $\beta$-glucosidase in Stachybotrys atra with similar characteristics. The inactivity of the saprophytic strains toward $\beta$-methyl-D-glucoside can be compared to the normally slow cleavage of short chained alkyl aglycons by other organisms (Duerksen \& Halvorson, 1958). Inability to hydrolyse $\beta$-methyl-D-xyloside and $\beta$-methyl-D-arabinopyranoside points to the absolute specificity of the enzyme for carbon atoms 4 and 5 . This contrasts with the $\beta$-glucosidase from almonds which does not exhibit such absolute specificity since $\beta$-xylosides and $\beta$-arabinosides are hydrolysed (Veibel, 1950). The $\beta$-glucosidase from Saccharomyces cerevisiae shows absolute specificity for carbon atom number 4 but does not for carbon atom number 5 indicating that $\beta$-glucosides and $\beta$-xylosides can be hydrolysed but $\beta$-galactosides and $\beta$-arabinosides cannot (Duerksen $\&$ Halvorson, 1958). The $\beta$-glucosidase from Stachybotrys atra requires an hydroxyl group at carbon atom number 4 but configuration is not important indicating that $\beta$-glucosides or $\beta$-galactosides can be hydrolysed (Jermyn, 1955).

Although all strains of Mycoplasma capable of glucose degradation exhibited activity toward $p$-nitrophenyl- $\beta$-D-glucoside, no activity was demonstrated toward $o$-nitrophenyl- $\beta$-D-galactoside even though the aglycon, $o$-nitrophenol, has been shown to promote more activity than $p$-nitrophenol when substituted to glucose (Pigman, 1944). This indicates that the inactivity is due to some characteristic of the glycon, presumably the configuration of the hydroxyl group at carbon atom number 4.

The work reported in this paper was supported in part by research grant USPH AI-04410-02 and training grant USPH 1 T 1 AI 232-01 from the National Institute of Allergy and Infectious Diseases, U.S. Public Health Service.

\section{REFERENCES}

Conchie, J. (1954). Glucosidase from rumen liquor. Biochem.J. 58, 552.

Duerksen, J. D. \& Halvorson, H. O. (1958). Purification and properties of an inducible $\beta$-glucosidase of yeast. J. biol. Chem. $233,1113$.

GEE, M. (1963). Thin layer chromatography of some methylated glycosides. Anal. Chem. 35, 350.

Gomori, G. (1955). Preparations of buffers for use in enzyme studies. In Methods of Enzymology. Ed. by S. P. Colowick \& N. O. Kaplan, vol. 1, p. 138. New York: Academic Press Inc. 
Hash, J. H. \& KING, K. W. (1958). Some properties of an aryl $\beta$-glucosidase from culture filtrates of Myrothecium verrucaria. J. biol. Chem. 232, 395.

Jermyn, M. A. (1955). Fungal cellulases. Aust.J. biol. Sci. 7, 541.

LECce, J. G. \& Monton, H. E. (1954). Metabolic studies on three strains of pleuropneumonia-like organisms isolated from man. J. Bact. 66, 646.

Morton, H. E., Smith, P. F. \& Leberman, P. R. (1951). Investigation of the cultivation of pleuropneumonia-like organisms from humans. Am.J.Syph. Gonorrhea vener. Dis. 35, 361.

Park, J. T. \& Johnson, M. J. (1949). A submicrodetermination of glucose. J. biol. Chem. $181,149$.

Pigman, W. W. (1944). Specificity, classification and mechanism of action of the glycosidases. In $A d v$. Enzymol. 4, 41.

Rothblat, G. H. \& Smith, P. F. (1961). Nonsaponifiable lipids of representative pleuropneumonia-like organisms. J. Bact. 82, 479.

Sмiтн, P. F. (1955). Amino acid metabolism by pleuropneumonia-like organisms. I. General catabolism. J. Bact. 70, 552.

Smiтн, P. F. (1959). Cholesterol esterase activity of pleuropneumonia-like organisms. J. Bact. 77, 682.

Sмiтн, P. F. (1963a). The carotenoid pigments of Mycoplasma. J. gen. Microbiol. 32, 307.

Sмrтн, P. F. (1963b). The role of sterols in the growth and physiology of pleuropneumonialike organisms. In Recent Progress in Microbiology. Ed. by N. E. Gibbons, p. 518. Toronto: University of Toronto Press.

Smrth, P. F. \& Rothblat, G. H. (1962). Comparison of lipid composition of pleuropneumonia-like and L-type organisms. J. Bact. 83, 500.

Veibel, S. (1950). $\beta$-Glucosidases. In The Enzymes, Part I. Ed. by J. B. Sumner \& K. Myrback, vol. 1, p. 583. New York: Academic Press, Inc. 